\title{
Development of a novel loop-mediated isothermal amplification assay for the detection of lipolytic Pseudomonas fluorescens in raw cow milk from north China
}

\author{
Liang Xin, ${ }^{*}$ Lanwei Zhang, ${ }^{*} \dagger^{1}$ Zhaoxu Meng, ${ }^{*}$ Kai Lin, ${ }^{*}$ Shuang Zhang,, Xue Han, ${ }^{*}$ HuaXi Yi, $\dagger^{1}$ \\ and Yanhua Cui* \\ *Department of Food Science and Engineering, Harbin Institute of Technology, Harbin 150090, China \\ †College of Food Science and Engineering, Ocean University of China, Qingdao 266003, China \\ łFood College, Northeast Agricultural University, Harbin 150030, China
}

\begin{abstract}
Lipases secreted by psychrotrophic bacteria are known to be heat resistant and can remain active even after the thermal processing of milk products. Such enzymes are able to destabilize the quality of milk products by causing a rancid flavor. Rapid detection of a small amount of heat-resistant lipase-producing psychrotrophic bacteria is crucial for reducing their adverse effects on milk quality. In this study, we established and optimized a novel loop-mediated isothermal amplification (LAMP) assay for the detection of Pseudomonas fluorescens in raw cow milk, as the most frequently reported heat-resistant lipase-producing bacterial species. Pseudomonas fluorescens-specific DNA primers for LAMP were designed based on the lipase gene sequence. Reaction conditions of the LAMP assay were tested and optimized. The detection limit of the optimized LAMP assay was found to be lower than that of a conventional PCR-based method. In pure culture, the detection limit of the LAMP assay was found to be 4.8 $\times 10^{1} \mathrm{cfu} /$ reaction of the template DNA, whereas the detection limit of the PCR method was $4.8 \times 10^{2} \mathrm{cfu} /$ reaction. Evaluation of the performance of the method in P. fluorescens-contaminated pasteurized cow milk revealed a detection limit of $7.4 \times 10^{1} \mathrm{cfu} /$ reaction, which was $10^{2}$ lower than that of the PCR-based method. If further developed, the LAMP assay could offer a favorable on-farm alternative to existing technologies for the detection of psychotrophic bacterial contamination of milk, enabling improved quality control of milk and milk products.
\end{abstract}

Received February 16, 2017.

Accepted June 17, 2017.

${ }^{1}$ Corresponding authors: zhanglw@hit.edu.cn and yihx@ouc.edu.cn
Key words: loop-mediated isothermal amplification, psychrotrophic bacteria, Pseudomonas fluorescens, raw cow milk

\section{INTRODUCTION}

Cold storage and transportation of raw cow milk creates favorable conditions for the growth of psychrotrophic bacteria (Baur et al., 2015). Psychrotrophic bacteria account for less than $10 \%$ of the total microbiota found in fresh raw cow milk, but dominate the microbial community during cold storage (Rasolofo et al., 2010; Weber et al., 2014). A large number of psychrotrophic bacteria have been identified as belonging to the genus Pseudomonas (Quigley et al., 2013; von Neubeck et al., 2015). These bacteria can grow to high numbers during refrigerated storage, and many can also produce heatstable extracellular lipases (Dogan and Boor, 2003). Among the genus, Pseudomonas fluorescens exhibits the highest metabolic and lipolytic activity in refrigerated milk (Capodifoglio et al., 2016; Stuknytè et al., 2016). The lipolytic enzymes remain active, even after thermal processing steps that can destroy the bacteria themselves (Vithanage et al., 2016). The lipolytic enzymes hydrolyze triglycerides, causing changes in the flavor of the milk, turning it rancid, unclean, soapy, or bitter tasting, and leading to the product being rejected outright (Capodifoglio et al., 2016). The effects are even more of a problem in dairy products with a long shelf life, such as UHT milk (Decimo et al., 2014).

Because it is difficult to inactivate the enzymes secreted by psychotropic bacteria in affected milk using existing technologies, it is very important to develop more vigilant test methods for their detection in raw cow milk. The culture-dependent method for the detection of microorganisms in biological samples is both laborious and time consuming, and can thus result in a missed opportunity to control and improve the quality of raw cow milk. Culture-independent methods have been 
shown to be useful for the rapid and specific detection of microorganisms (Cho et al., 2014; Bosward et al., 2016; Cornelissen et al., 2016). As a nucleic acid-based amplification method, loop-mediated isothermal amplification (LAMP) has been developed for the rapid detection of a small amount of microorganisms. Four to 6 specific primers have been designed for use in LAMP, together with a strand-displacing Bst DNA polymerase that can amplify the target DNA by up to $10^{9}$ copies per hour (Notomi et al., 2000). In addition, LAMP proceeds under isothermal conditions and does not require expensive and sophisticated instruments (Cornelissen et al., 2016). Positive LAMP reactions can be judged by the naked eye following DNA amplification with a thermal cycler and gel electrophoresis (Kumar and Mondal, 2015). Additionally, they can be judged by the formation of optic visible magnesium pyrophosphate (turbidity) or by fluorescence using DNA-intercalating dyes, the latter of which enables real-time monitoring of LAMP reactions to be performed by measuring the fluorescence.

In this study, a specific primer set based on the lipase gene sequence of $P$. fluorescens was designed and used to establish a fluorescence-based real-time LAMP assay, with the aim of developing a more specific approach that has a lower detection limit for the detection and quantification of $P$. fluorescens as a potent producer of heat-resistant lipase in raw cow milk.

\section{MATERIALS AND METHODS}

\section{Strains and Cultures}

Twenty-one different lipolytic Pseudomonas isolated strains from 6 different Pseudomonas species were identified in raw cow milk originating from north China in our previous study (Xin et al., 2017). These are listed, along with other standard strains that are commonly isolated from raw cow milk, in Table 1. All of these strains were used to evaluate the specificity of the newly developed LAMP assay. Pseudomonas fluorescens ATCC 13525 acted as the positive control in this evaluation. Pseudomonas fluorescens 38 was used for the optimization of the LAMP assay and to test the detection limit of the assay. The strains were cultured in $10 \mathrm{~mL}$ of $\mathrm{LB}$ medium for $16 \mathrm{~h}$ at $25^{\circ} \mathrm{C}$ (Pseudomonas spp.) or for $24 \mathrm{~h}$ at $37^{\circ} \mathrm{C}$ (non-Pseudomonas spp.).

\section{Bacterial DNA Extraction}

The DNA content of all strains listed in Table 1, cultured in pure culture, was extracted using the E. Z. N. A. Bacterial DNA Kit (Omega Bio-Tek, Norcross, GA) for use in LAMP and PCR assays.

\section{Primers for LAMP and PCR}

The primer set for use in LAMP was designed based on the conserved gene sequence of the $P$. fluorescens lipase using Primer Explorer V4 software (http:// primerexplorer.jp/elamp4.0.0/index.html). The primer set included 2 outer primers (F3 and B3) and 2 inner primers (FIP and BIP). The primer sequences are shown in Table 2. The PCR was performed with primers F3 and B3. Primers were synthesized by Sangon Biotech Co. Ltd. (Shanghai, China).

\section{Optimization of LAMP Reaction Conditions}

We initially adopted the conditions reported by Notomi et al. (2000) as the default LAMP reaction conditions. Thereafter, we optimized the reaction conditions by evaluating the effects of adjusting the following reaction variables on the visualized intensity of electrophoretic bands produced by gel electrophoresis of the amplified reaction products: $\mathrm{Mg}^{2+}$ concentration (0.0, $4.0,6.0,8.0,10.0$, and $12.0 \mathrm{mmol} / \mathrm{L}$ ), deoxynucleotide triphosphate $(\mathbf{d N T P})$ concentration $(0.0,0.4,0.8,1.2$, 1.6 , and $2.0 \mathrm{mmol} / \mathrm{L}$ ), Bst DNA polymerase (New England Biolab, Ipswich, MA) concentration (0.0, 0.4, 0.8, $1.2,1.6$, and $2.0 \mu \mathrm{L}$ ), inner/outer primer ratio (1:1, $2: 1,4: 1,6: 1,8: 1$, and $10: 1)$, reaction time $(20,30,40$, $50,60$, and $70 \mathrm{~min})$, and temperature $(60,61,62,63$, 64 , and $65^{\circ} \mathrm{C}$ ). After reaction completion, the reaction mixtures were inactivated at $80^{\circ} \mathrm{C}$ for $5 \mathrm{~min}$. A negative control, consisting of an identical reaction mixture containing distilled water in place of the DNA template, was included in each reaction run. The LAMP reaction products were analyzed using $2.5 \%$ agarose gel electrophoresis at $100 \mathrm{~V}$ for $40 \mathrm{~min}$.

A real-time LAMP reaction system was developed by replacing $0.3 \mu \mathrm{L}$ of double-distilled $\mathrm{H}_{2} \mathrm{O}$ with $0.3 \mu \mathrm{L}$ of a 1:200 dilution of 10,000 $\times$ SYBR green I (SigmaAldrich Co., St. Louis, MO) in the optimized LAMP reaction system. Real-time LAMP reactions were conducted in an ABI 7500 Real-Time PCR system (Applied Biosystems, Foster City, CA) under the optimized reaction conditions, during which fluorescence of the SYBR Green I was measured every $45 \mathrm{~s}$.

\section{PCR Amplification Conditions}

The PCR was carried out in a MyCycler thermal cycler (Bio-Rad, Hercules, CA). Reactions were carried out in a total volume of $25 \mu \mathrm{L}$ containing $2 \times \mathrm{PCR}$ Mix, 20 pmol of each primer, $2 \mu \mathrm{L}$ of template DNA, and distilled water. Amplification conditions were $94^{\circ} \mathrm{C}$ for $5 \mathrm{~min}$, followed by $94^{\circ} \mathrm{C}$ for $30 \mathrm{~s}, 56^{\circ} \mathrm{C}$ for $30 \mathrm{~s}$, and $72^{\circ} \mathrm{C}$ for $30 \mathrm{~s}$. This sequence was repeated for 35 cycles. 
Table 1. Comparative specificity of the real-time loop-mediated isothermal amplification (LAMP) assay, and conventional PCR assay, for the detection of Pseudomonas fluorescens

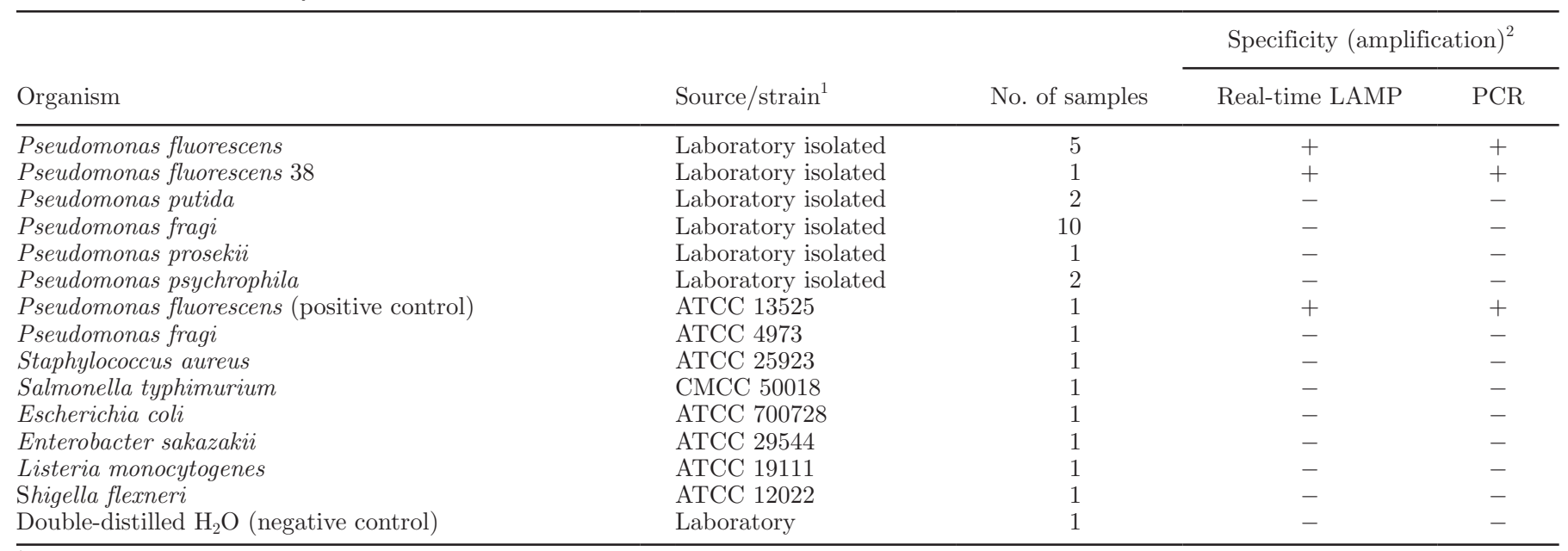

${ }^{1}$ ATCC = American Type Culture Collection, CMCC = China Microbiological Culture Collection, China.

${ }^{2}$ Where + indicates amplification and - indicates no amplification.

A final extension step was done at $72^{\circ} \mathrm{C}$ for $10 \mathrm{~min}$. The resulting PCR amplicons were run on a $2.5 \%$ agarose gel at $100 \mathrm{~V}$ for $40 \mathrm{~min}$. Gels were then stained with ethidium bromide and visualized under a UV transilluminator (Gel Doc XR, Bio-Rad).

\section{Detection Limit and Specificity of Real-Time LAMP Assay in Pure Culture}

The detection limit of the real-time LAMP reaction system was analyzed and compared with that of the PCR system. The detection limits of the 2 systems in pure culture were determined using 10-fold serial dilutions of cultured P. fluorescens 38. Exact cell numbers were determined by standard plate counting. The cultures were 10-fold serially diluted in sterilized normal saline and aliquots $(1 \mathrm{~mL})$ of each dilution were used to prepare DNA templates before DNA extraction as described above. Aliquots $(2 \mu \mathrm{L})$ of each template were tested by both real-time LAMP and PCR assay systems. In the pure culture of $P$. fluorescens 38 , the transformation efficiency was calculated using the equation $\mathrm{cfu} / \mathrm{mL} \times 3 \times 4 \times 10^{-2}$.
The specificity of the real-time LAMP assay system was examined using the DNA extracted from all the bacteria listed in Table 1 (consisting of 21 different lipolytic strains and other standard strains commonly found in raw cow milk). The concentrations of all bacterial suspensions were adjusted to $10^{6} \mathrm{cfu} / \mathrm{mL}$.

\section{Detection Limits of Real-Time LAMP Assay for Artificial Contamination of Milk with P. fluorescens}

Pasteurized whole milk obtained from Wondersun Harbin Dairy Co. Ltd. (Harbin, Heilongjiang, China) was artificially inoculated with cultured P. fluorescens 38 following the same procedure already described in relation to the analysis of the detection limit of realtime LAMP in pure culture, except that pasteurized milk was used in the dilution. The DNA in the inoculated sample was extracted according to the procedure described by Yang et al. (2014). Noninoculated milk was used as a negative control. The real-time LAMP assay and conventional PCR assay were performed on the extracted DNA samples to estimate and compare their detection limits in pasteurized whole cow milk.

Table 2. Constructed primer sequences for Pseudomonas fluorescens lipase gene

\begin{tabular}{ll}
\hline Primer $^{1}$ & Sequence \\
\hline F3 & 5'-CGAAGCGTGCAGAAGGC-3' \\
B3 & 5'-GTGCCGCGAAAACCGA-3' \\
FIP & 5'-CTTTTCGCCGAAGAACGTGCCCTTTTCATCAGCGCCAGCACTCTT-3' \\
BIP & 5'-GCTATACCACGGCCCAGGTCTTTTTGCCGATTCCTGCAACTG-3' \\
\hline
\end{tabular}

${ }^{1}$ Two outer primers (F3 and B3) and 2 inner primers (FIP and BIP). 


\section{RESULTS}

\section{Optimization of LAMP Reaction Conditions}

The effects of the reaction variables on the appearance and intensity of electrophoretic bands produced by the reaction products from the LAMP assay system are shown in Figure 1. As shown in Figure 1a, the ladder-like electrophoretic bands appeared when the $\mathrm{Mg}^{2+}$ concentration reached $6.0 \mathrm{mmol} / \mathrm{L}$ in the reaction system, and were brightest at a concentration of 8.0 $\mathrm{mmol} / \mathrm{L}$. Figure 1b illustrates that the bands became apparent at dNTP concentrations of 0.4 to $2.0 \mathrm{mmol} / \mathrm{L}$, and that the brightness of the bands was greatest, and similar, at dNTP concentrations of 1.6 and $2.0 \mathrm{mmol} / \mathrm{L}$. The effects of different levels of Bst DNA polymerase content are shown in Figure 1c. Bands were visible when $0.4 \mu \mathrm{L}$ of Bst DNA polymerase was added to the reaction system, and were clear and bright when $0.8 \mu \mathrm{L}$ was added. Electrophoretic bands were detectable at a ratio of 4:1 inner:outer primers, and were brightest with an inner:outer primer content ratio of 8:1 (Figure 1d). For reaction temperature, the brightest amplification bands were observed at $64^{\circ} \mathrm{C}$ (Figure 1e). The brightest electrophoretic bands were produced at a reaction time of $50 \mathrm{~min}$ (Figure 1f). According to these observations, we determined the optimal LAMP reaction conditions as being $\mathrm{Mg}^{2+}$ concentration, $8.0 \mathrm{mmol} / \mathrm{L}$; Bst DNA polymerase content, $0.8 \mu \mathrm{L}$; dNTP concentration, 1.6 $\mathrm{mmol} / \mathrm{L}$; inner:outer primer ratio, 8:1; temperature, $64^{\circ} \mathrm{C}$; and reaction time, $50 \mathrm{~min}$.

\section{Detection Limit of Real-Time LAMP Method}

The detection limit of the real-time LAMP assay was evaluated by genomic DNA extracted from serial dilution P. fluorescens 38, and compared with the detection limit of the PCR method. The results are shown in Figure 2. Concentrations of $4.8 \times 10^{5}$ to $4.8 \times 10^{1} \mathrm{cfu}$ per reaction of the template DNA could be amplified by the real-time LAMP assay system, whereas concentrations below this range were not detectable (no amplification curves were observed; Figure 2a). In contrast, the PCR system required at least $4.8 \times 10^{2} \mathrm{cfu}$ of bacteria per reaction to generate a visible band on the agarose gel (Figure 2b).

\section{Specificity of Real-Time LAMP Assay}

The results of the evaluation of the specificity of the real-time LAMP assay for the detection of P. fluorescens as distinct from other related bacterial species, in pure culture, are presented in Table 1. Pseudomo- nas fluorescens ATCC 13525 was used as the positive control. Sterile double-distilled $\mathrm{H}_{2} \mathrm{O}$ was used as the negative control. The assay system detected all $6 P$. fluorescens bacterial strains as well as standard strain $P$. fluorescens ATCC 13525 as positive, including $P$. fluorescens 38 . All other strains were correctly detected as negative.

\section{Ability of Real-Time LAMP Assay to Detect $P$. fluorescens Contamination in Milk}

To determine the comparative detection limits of the developed real-time LAMP assay and PCR assay for the detection of $P$. fluorescens in milk, pasteurized whole milk was artificially contaminated with different cell densities of P. fluorescens 38. The PCR assay positively detected as few as $7.4 \times 10^{3} \mathrm{cfu} /$ reaction of the template DNA. In contrast to this, the developed LAMP assay had a lower detection limit of $7.4 \times 10^{1}$ cfu/reaction of template DNA (Figure 3).

\section{DISCUSSION}

There is a current need for the development of simple, rapid methods for the detection of psychrotrophic bacteria producing heat-resistant lipase in raw cow milk. The availability of such methods would enable better control of such bacteria in milk, improving the quality of dairy products and decreasing the economic costs associated with rejection of spoiled milk. Bacteriological methods, immunological methods, and molecular methods, such as multiplex PCR and real-time PCR, have all been applied to the detection of microorganisms in food (Alhogail et al., 2016; Nagaraj et al., 2016; Xu et al., 2017). However, these methods are not always feasible for use on farm or in modest-sized microorganism testing laboratories because they are often expensive and require the use of bulky apparatus. Moreover, such methods typically take in the region of $2 \mathrm{~h}$ to produce results. Recently, LAMP has been developed as a nucleic acid amplification technique and is now widely used for the detection of foodborne bacteria, viruses, and parasites (Abirami et al., 2016; Tian et al., 2016; Yang et al., 2016). This method possesses many advantages over the aforementioned conventional methods, such as a requirement for a simple heating block rather than an expensive thermal cycler. In addition, the LAMP method is typically has a detection limit that is 1 to 2 orders of magnitude lower than the PCR method. It also has a shorter turnaround time (30-60 min) and supports a variety of methods for the visualization and interpretation of results (Fischbach et al., 2015). 
The aim of the present study was to explore the possibilities of LAMP as a method for the detection of psychrotrophic bacteria that produced heat-resistant lipase in raw cow milk. Pseudomonas fluorescens is one of the major psychrotrophic bacteria producing heat-resistant lipase in raw cow milk. Pseudomonas fluorescens 38 has been isolated from raw cow milk obtained from north China and has a high heat-resistant lipase-producing ability (Xin et al., 2017). On this basis, P. fluorescens 38 was selected and used to optimize the LAMP assay and to determine its limit of detection. We designed a real-time LAMP assay based on the lipase gene of $P$. fluorescens 38.

To develop a rapid method that has a lower detection limit for the detection of $P$. fluorescens that produce heat-resistant lipase, we optimized the LAMP reaction a

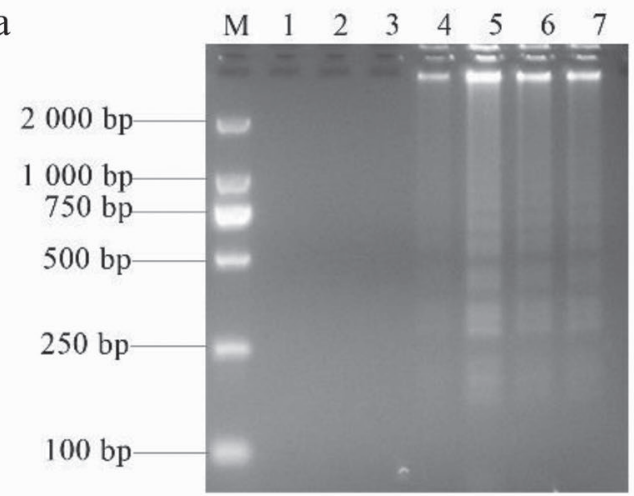

c

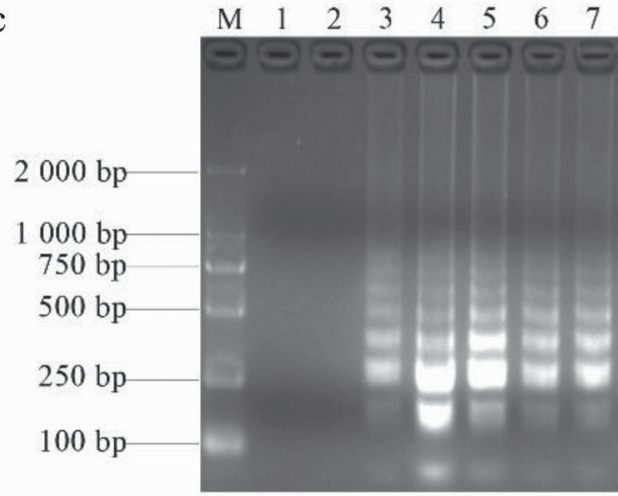

$\mathrm{e}$

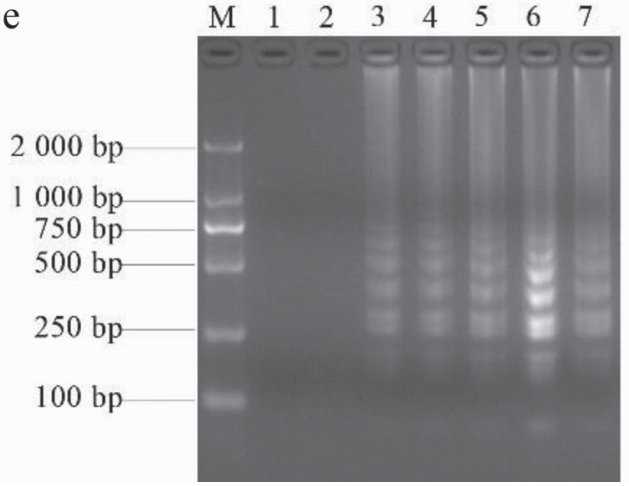

b
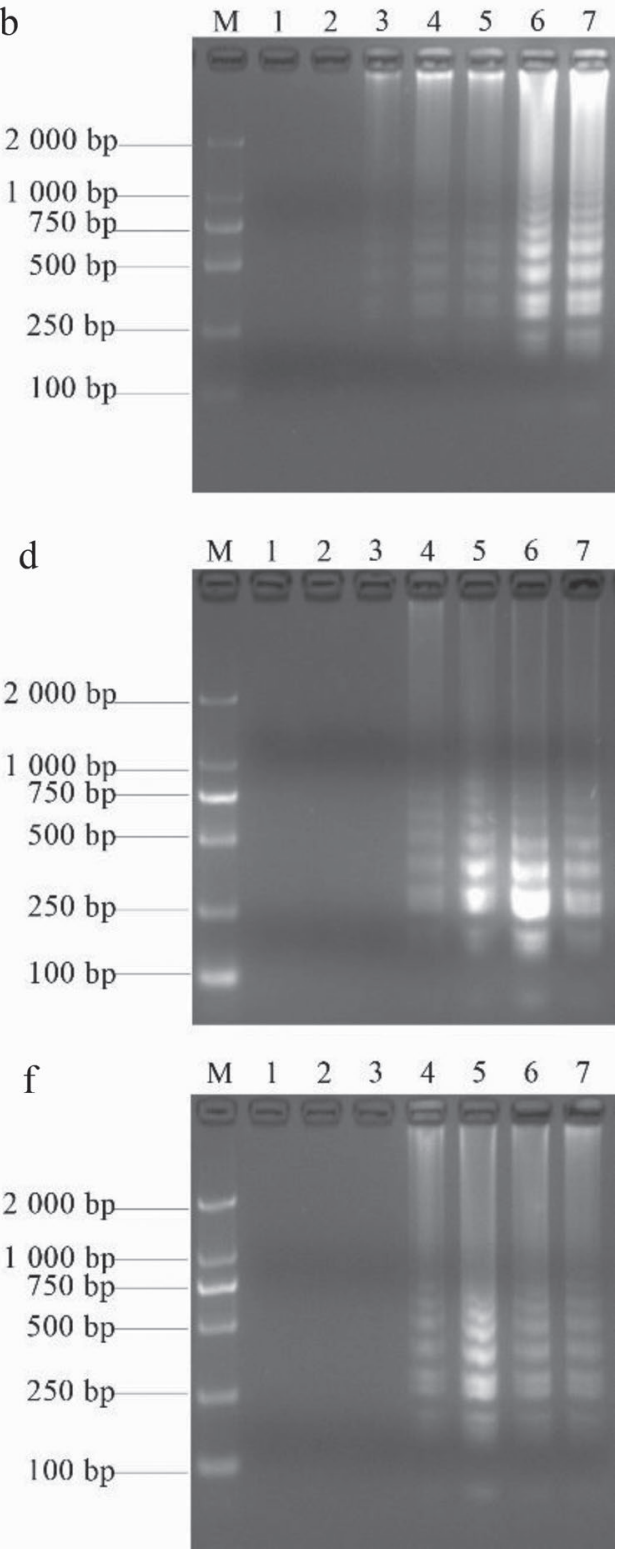

Figure 1. Effects of $\mathrm{Mg}^{2+}$ concentration, deoxynucleotide triphosphate (dNTP) concentration, Bst DNA polymerase content, inner/outer primer ratio, temperature, and reaction time on electrophoretic visualization of bands produced from loop-mediated isothermal amplification (LAMP) reaction products. (a) Effects of $\mathrm{Mg}^{2+}$ concentration. 1: negative control; 2: $0.0 \mathrm{mmol} / \mathrm{L} ; 3: 4.0 \mathrm{mmol} / \mathrm{L} ; 4: 6.0 \mathrm{mmol} / \mathrm{L} ; 5: 8.0 \mathrm{mmol} / \mathrm{L}$; 6: $10.0 \mathrm{mmol} / \mathrm{L}$; and 7: $12.0 \mathrm{mmol} / \mathrm{L}$. (b) Effects of dNTP concentration. 1: negative control; 2: $0.0 \mathrm{mmol} / \mathrm{L} ; 3: 0.4 \mathrm{mmol} / \mathrm{L} ; 4: 0.8 \mathrm{mmol} / \mathrm{L} ; 5$ : $1.2 \mathrm{mmol} / \mathrm{L} ; 6: 1.6 \mathrm{mmol} / \mathrm{L}$; and 7: $2.0 \mathrm{mmol} / \mathrm{L}$. (c) Effect of Bst DNA polymerase content. 1: negative control; 2: $0.0 \mu \mathrm{L} ; 3: 0.4 \mu \mathrm{L} ; 4: 0.8 \mu \mathrm{L}$; 5: $1.2 \mu \mathrm{L} ; 6: 1.6 \mu \mathrm{L}$; and 7: $2.0 \mu \mathrm{L}$. (d) Effects of inner/outer primer ratio. 1: negative control; 2: 1:1; 3: 2:1; 4: 4:1; 5: 6:1; 6: 8:1; and 7: 10:1. (e) Effects of temperature. 1: negative control, 2: $60^{\circ} \mathrm{C}, 3: 61^{\circ} \mathrm{C}, 4: 62^{\circ} \mathrm{C}, 5: 63^{\circ} \mathrm{C}, 6: 64^{\circ} \mathrm{C}$, and $7: 65^{\circ} \mathrm{C}$. (f) Effects of reaction time. $1:$ negative control; 2: $20 \mathrm{~min}$; 3: $30 \mathrm{~min}$; 4: $40 \mathrm{~min}$; 5: $50 \mathrm{~min}, 6$ : $60 \mathrm{~min}$, and 7: $70 \mathrm{~min}$. In all panels, M represents the molecular weight marker. 


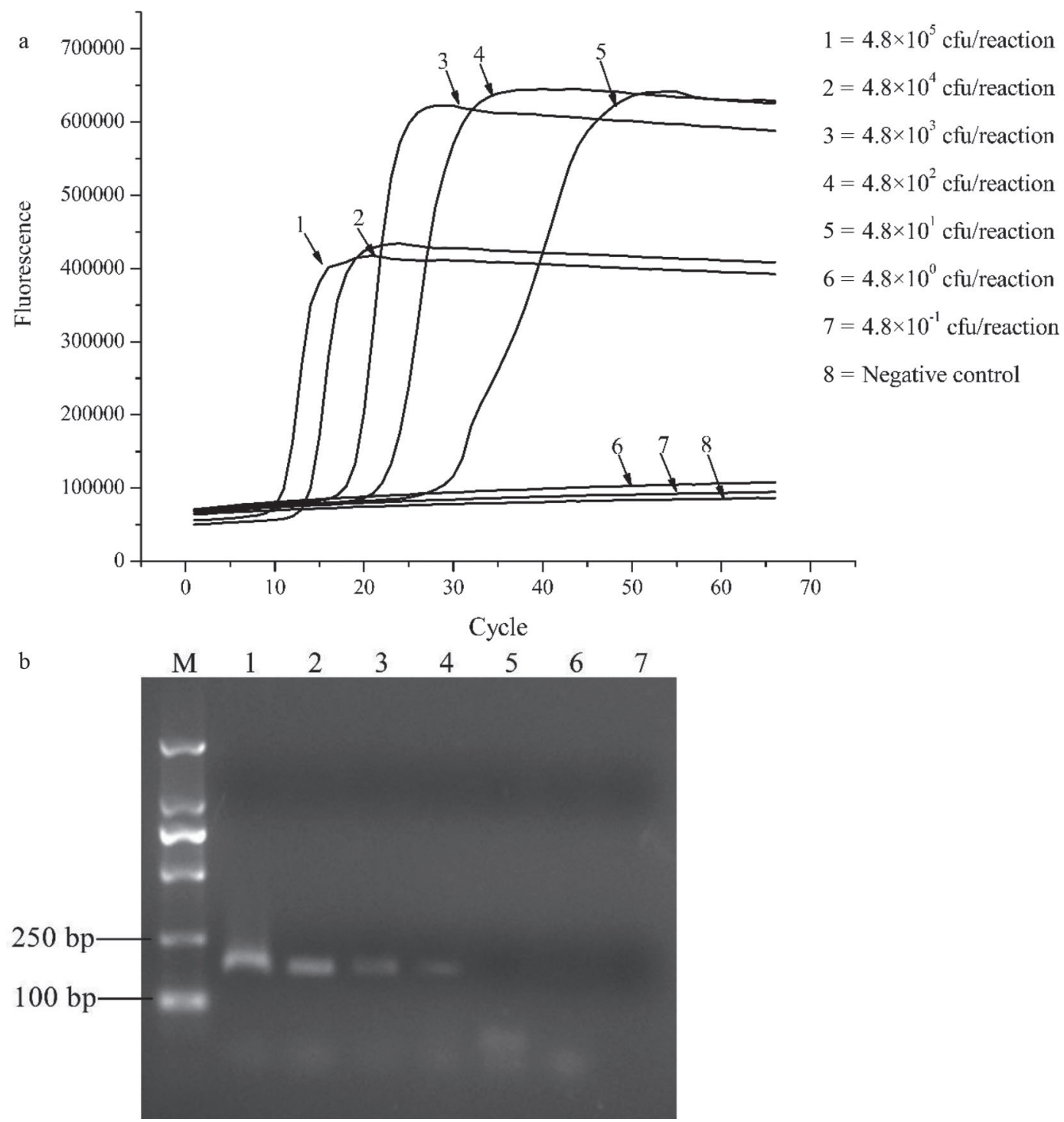

Figure 2. Detection limit of the real-time loop-mediated isothermal amplification (LAMP) assay (a) in comparison with the PCR assay and (b) for the detection of Pseudomonas fluorescens 38 amplified DNA. (a) Detection limit of the real-time LAMP assay at different colony-forming units/reaction concentrations. Real-time LAMP assays were performed using $4.8 \times 10^{5}$ to $4.8 \times 10^{-1}$ cfu/reaction of the template DNA. Sterile double-distilled $\mathrm{H}_{2} \mathrm{O}$ in place of the template DNA served as a negative control. (b) Detection limit of the PCR assay at different colony-forming units/reaction concentrations. Lane M: molecular weight marker; lanes $1,2,3,4,5,6$, and 7 represent $4.8 \times 10^{5}, 4.8 \times 10^{4}, 4.8 \times 10^{3}, 4.8 \times 10^{2}$, $4.8 \times 10^{1}, 4.8 \times 10^{0}$, and $4.8 \times 10^{-1} \mathrm{cfu} /$ reaction, respectively.

conditions via a series of single-factor experiments. In our future planned research, the influence of interactions among the variables on the reaction products will be considered. In the present study, the real-time LAMP assay was established in combination with fluorescence quantification using a real-time PCR instrument. Under this system, the fluorescence signals could be continuously recorded and analyzed, which enables a significant time saving to be made (compared with conventional methods) in the confirmation of results
(40 min saved). Portable fluorescence detectors have already been applied to on-site detection of microorganisms and have been shown to deliver the same results as fluorescence quantification PCR instruments (Fu et al., 2016). Moreover, a battery-operated portable fluorescence detector can be used in conjunction with the LAMP assay system (Ye et al., 2015; Lee et al., 2016). Furthermore, because the LAMP reaction tubes are not opened until the reaction has completed, the potential risks of cross-contamination and false- 


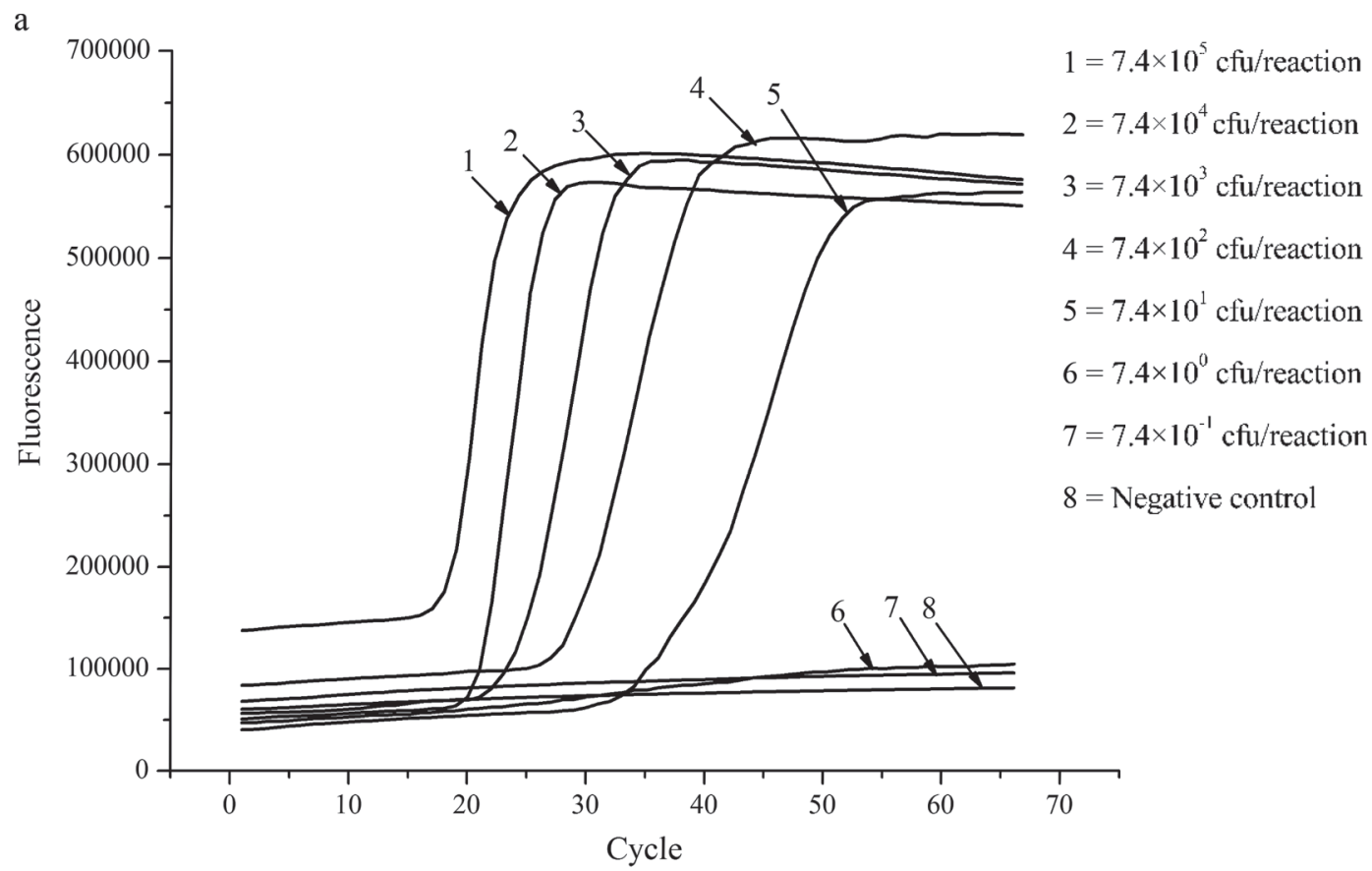

$\mathrm{b}$

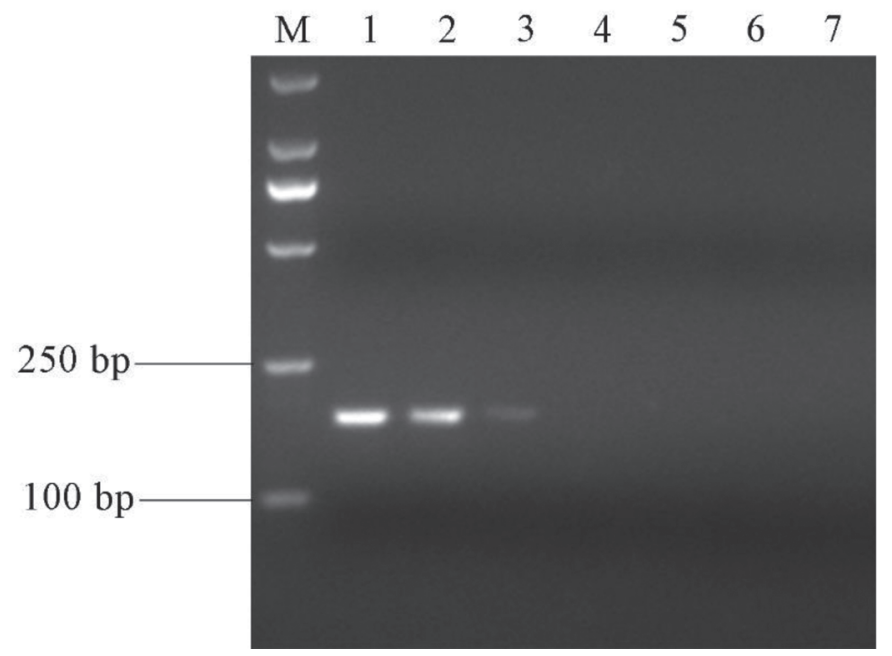

Figure 3. Comparative detection limit of the real-time loop-mediated isothermal amplification (LAMP) assay (a) and the PCR assay system (b), for the detection of Pseudomonas fluorescens contamination in milk. (a) Detection limit of the real-time LAMP assay at different colonyforming units/reaction of the template DNA. The LAMP assays were performed using $7.4 \times 10^{5}$ to $7.4 \times 10^{-1}$ cfu/reaction of the template DNA. Sterile double-distilled $\mathrm{H}_{2} \mathrm{O}$ in place of the template DNA served as a negative control. (b) Detection limit of the PCR assay at different colony-forming units/reaction of the template DNA. Lane M: molecular weight marker; lanes $1,2,3,4,5,6$, and $7: 7.4 \times 10^{5}, 7.4 \times 10^{4}, 7.4 \times$ $10^{3}, 7.4 \times 10^{2}, 7.4 \times 10^{1}, 7.4 \times 10^{0}$, and $7.4 \times 10^{-1} \mathrm{cfu} /$ reaction, respectively.

positives are significantly reduced compared with existing methods. A further benefit of the real-time assay system is that it has the ability to be scaled up for high-throughput detection and to be used for accurate target quantification (Tang et al., 2016). The detection limit of the developed LAMP assay was compared with a conventional PCR assay system in the present study. Our results revealed that the detection limit of the
LAMP assay was 10 times lower than that of the PCR assay in pure culture (detection limit of $4.8 \times 10^{1} \mathrm{cfu} /$ reaction of template DNA vs. $4.8 \times 10^{2} \mathrm{cfu} /$ reaction, respectively). Although our preliminary findings have shown that the LAMP primers we used (when applied under the specified reaction conditions) are specific for $P$. fluorescens, we plan to conduct further studies with a greater number of species and strains of $P$. fluorescens 
that produce heat-resistant lipase and other bacteria to further evaluate the detection limit and specificity of the method.

An important aspect of our study was to test the developed LAMP assay protocol for the detection of lipolytic P. fluorescens in pasteurized whole cow milk, where its application could be used to control the quality of milk in practice. The method of genomic DNA extraction is key to the successful application of the LAMP method in this context, and must be simple, efficient, and low cost. Milk consists of several macromolecules, such as proteins and fats, which could potentially interfere with the DNA amplification efficiency. Thus, removal of these macromolecules is required. Around $80 \%$ of total milk proteins are caseins, which are incorporated into the micelle structures together with a high proportion of the available calcium and inorganic phosphate. The use of EDTA can chelate the calcium ions and eventually disrupt the micelles, resulting in the casein and whey moving into the supernatant. Triton X-100 has also been used successfully to remove residual lipids (Kumar and Mondal, 2015). Centrifugation can also remove a proportion of the protein and fat present in milk. Previous studies comparable to ours have combined centrifugation with the DNA extraction kit to extract the genomic DNA in milk (Yang et al., 2011; Song et al., 2012). Although these modified extraction kits result in a satisfactory detection limit, the detection cost is elevated by the addition of the extraction reagents and the detection time is longer. A LAMP-compatible rapid and simple method to increase the DNA yield is therefore desirable. The LAMP assay was revealed to have a similar limit of detection in pasteurized cow milk and pure culture. Comparing this to the existing literature, 2 studies have previously reported that the results produced from the LAMP assay in detecting $P$. fluorescens in pure culture and in artificially contaminated milk samples were of a similar order of magnitude (Cho et al., 2014; Ye et al., 2015). Three out of 5 published studies have suggested that the detection limit of the method is lower in pure culture than in milk (Yang et al., 2011; Wang et al., 2015; Cornelissen et al., 2016). The DNA extraction method used is an important factor that may affect the results obtained (Sowmya et al., 2012). In the present study, when compared with the conventional PCR method, the detection limit of LAMP assay was found to be $10^{2}$ times lower than the PCR method in milk. This difference between the 2 methods was not as evident when they were applied to analysis of $P$. fluorescens in pure cultures, suggesting that the PCR method may have been inhibited by certain compounds in the milk. This is consistent with a previous report that
LAMP is less affected by inhibitory substances present in biological samples (such as milk) than conventional PCR (Sowmya et al., 2012; Cho et al., 2014; Bosward et al., 2016). According to Machado et al. (2013), fat is a PCR inhibitor. The average reaction time values of real-time LAMP were, respectively, 10 to 28 cycles and 17 to 32 cycles when the DNA template concentrations in the pure bacterial cultures and artificially contaminated milk samples ranged from $4.8 \times 10^{5}$ to $4.8 \times 10^{1}$ $\mathrm{cfu} /$ reaction and $7.4 \times 10^{5}$ to $7.4 \times 10^{1} \mathrm{cfu} /$ reaction of the template DNA, respectively. This suggests that the real-time LAMP assay was somewhat influenced by the presence of compounds in the milk.

As a DNA-based detection method, LAMP cannot distinguish between DNA arising from viable cells and that arising from dead cells (Chen et al., 2011; Wan et al., 2012). In the present research, this is an advantage in terms of being able to accurately assess the potential contamination of heat-resistant lipase in milk because heat-resistant lipase are still active in contaminated dairy products even if the parent bacteria ( $P$. fluorescens) has been destroyed. In this sense, a LAMP detection method is more accurate than a culture-dependent method.

In the present study, lipolytic P. fluorescens were successfully detected in pasteurized whole milk. It has previously been shown that extracellular enzymes secreted by psychrotrophic bacteria, mostly Pseudomonas species, are well-known causes of spoilage in other matrices including dairy products and meat (Rajmohan et al., 2002; Caldera et al., 2016). On this basis, we plan to further evaluate the LAMP method for the detection of psychotropic bacteria and their heat-resistant enzymes on additional food matrices.

\section{CONCLUSIONS}

This study has developed and optimized a LAMP assay for the detection of lipolytic P. fluorescens in raw cow milk that compares favorably with a conventional PCR-based method. The procedure offers a simple, rapid, species-specific method that has a lower detection limit compared with existing methodologies and has the potential to improve the control of heat-resistant lipase in commercially produced raw cow milk. The challenges that remain before the LAMP assay is suitable for use in the field include the availability of a compatible rapid isolation procedure for extraction of DNA from bacteria in raw cow milk. Nevertheless, once fully developed, the LAMP assay method has the potential to make the detection of heat-resistant lipase-producing P. fluorescens both easier and faster and, furthermore, could be applied across the whole 
of China, thereby delivering significant economic and societal benefits.

\section{ACKNOWLEDGMENTS}

This work was financially supported by the Bring in Talent Foundation of the Harbin Institute of Technology (AKBQ18600001-HIT, China), the National Natural Science Foundation of China (no. 31571850), and the Province Natural Science Foundation of Heilongjiang (QC2016024, China).

\section{REFERENCES}

Abirami, N., H. Nidaullah, L.-O. Chuah, A. K. Shamila-Syuhada, S. R. Chandraprasad, N. Huda, H. Hasmaizal, and G. Rusul. 2016. Evaluation of commercial loop-mediated isothermal amplification based kit and ready-to-use plating system for detection of Salmonella in naturally contaminated poultry and their processing environment. Food Contr. 70:74-78.

Alhogail, S., G. Suaifan, and M. Zourob. 2016. Rapid colorimetric sensing platform for the detection of Listeria monocytogenes foodborne pathogen. Biosens. Bioelectron. 86:1061-1066.

Baur, C., M. Krewinkel, B. Kranz, M. von Neubeck, M. Wenning, S. Scherer, M. Stoeckel, J. Hinrichs, T. Stressler, and L. Fischer. 2015. Quantification of the proteolytic and lipolytic activity of microorganisms isolated from raw milk. Int. Dairy J. 49:23-29.

Bosward, K. L., J. K. House, A. Deveridge, K. Mathews, and P. A. Sheehy. 2016. Development of a loop-mediated isothermal amplification assay for the detection of Streptococcus agalactiae in bovine milk. J. Dairy Sci. 99:2142-2150.

Caldera, L., L. Franzetti, E. Van Coillie, P. De Vos, P. Stragier, J. De Block, and M. Heyndrickx. 2016. Identification, enzymatic spoilage characterization and proteolytic activity quantification of Pseudomonas spp. isolated from different foods. Food Microbiol. 54:142-153.

Capodifoglio, E., A. M. Vidal, J. A. Lima, F. Bortoletto, L. F. D'Abreu, A. C. Goncalves, A. C. Vaz, J. C. Balieiro, and A. S. Netto. 2016. Lipolytic and proteolytic activity of Pseudomonas spp. isolated during milking and storage of refrigerated raw milk. J. Dairy Sci. 99:5214-5223.

Chen, S., F. Wang, J. C. Beaulieu, R. E. Stein, and B. Ge. 2011. Rapid detection of viable Salmonellae in produce by coupling propidium monoazide with loop-mediated isothermal amplification. Appl. Environ. Microbiol. 77:4008-4016.

Cho, A.-R., H.-J. Dong, K.-H. Seo, and S. Cho. 2014. Development of a loop-mediated isothermal amplification assay for detecting Listeria monocytogenes prfA in milk. Food Sci. Biotechnol. 23:467-474.

Cornelissen, J. B., A. De Greeff, A. E. Heuvelink, M. Swarts, H. E. Smith, F. J. Van der Wal, and Health4Food-Dutch Mastitis Diagnostics Consortium. 2016. Rapid detection of Streptococcus uberis in raw milk by loop-mediated isothermal amplification. J. Dairy Sci. 99:4270-4281.

Decimo, M., S. Morandi, T. Silvetti, and M. Brasca. 2014. Characterization of gram-negative psychrotrophic bacteria isolated from Italian bulk tank milk. J. Food Sci. 79:M2081-M2090.

Dogan, B., and K. J. Boor. 2003. Genetic diversity and spoilage potentials among Pseudomonas spp. isolated from fluid milk products and dairy processing plants. Appl. Environ. Microbiol. 69:130-138.

Fischbach, J., N. C. Xander, M. Frohme, and J. F. Gloekler. 2015. Shining a light on LAMP assays-A comparison of LAMP visualization methods including the novel use of berberine. Biotechniques 58:189-194.

Fu, K., J. Li, Y. Wang, J. Liu, H. Yan, L. Shi, and L. Zhou. 2016. An innovative method for rapid identification and detection of Vibrio alginolyticus in different infection models. Front. Microbiol. 7:651.
Kumar, S., and K. K. Mondal. 2015. Visual detection of Escherichia coli contamination in milk and fruit juice using loop-mediated isothermal amplification. J. Food Sci. Technol. 52:7417-7424.

Lee, S.-Y., M.-J. Kim, Y. Hong, and H.-Y. Kim. 2016. Development of a rapid on-site detection method for pork in processed meat products using real-time loop-mediated isothermal amplification. Food Contr. 66:53-61.

Machado, S. G., D. M. S. Bazzolli, and M. C. D. Vanetti. 2013. Development of a PCR method for detecting proteolytic psychrotrophic bacteria in raw milk. Int. Dairy J. 29:8-14.

Nagaraj, S., S. Ramlal, J. Kingston, and H. V. Batra. 2016. Development of IgY based sandwich ELISA for the detection of staphylococcal enterotoxin G (SEG), an egc toxin. Int. J. Food Microbiol. 237:136-141.

Notomi, T., H. Okayama, H. Masubuchi, T. Yonekawa, K. Watanabe, N. Amino, and T. Hase. 2000. Loop-mediated isothermal amplification of DNA. Nucleic Acids Res. 28:E63.

Quigley, L., R. McCarthy, O. O'Sullivan, T. P. Beresford, G. F. Fitzgerald, R. P. Ross, C. Stanton, and P. D. Cotter. 2013. The microbial content of raw and pasteurized cow milk as determined by molecular approaches. J. Dairy Sci. 96:4928-4937.

Rajmohan, S., C. E. R. Dodd, and W. M. Waites. 2002. Enzymes from isolates of Pseudomonas fluorescens involved in food spoilage. J. Appl. Microbiol. 93:205-213.

Rasolofo, E. A., D. St-Gelais, G. LaPointe, and D. Roy. 2010. Molecular analysis of bacterial population structure and dynamics during cold storage of untreated and treated milk. Int. J. Food Microbiol. 138:108-118.

Song, L. Y., J. T. Li, S. P. Hou, X. D. Li, and S. Y. Chen. 2012. Establishment of loop-mediated isothermal amplification (LAMP) for rapid detection of Brucella spp. and application to milk and blood samples. J. Microbiol. Methods 90:292-297.

Sowmya, N., M. S. Thakur, and H. K. Manonmani. 2012. Rapid and simple DNA extraction method for the detection of enterotoxigenic Staphylococcus aureus directly from food samples: Comparison of PCR and LAMP methods. J. Appl. Microbiol. 113:106-113.

Stuknyte,, M., M. Decimo, M. Colzani, T. Silvetti, M. Brasca, S. Cattaneo, G. Aldini, and I. De Noni. 2016. Extracellular thermostable proteolytic activity of the milk spoilage bacterium Pseudomonas fluorescens PS19 on bovine caseins. J. Dairy Sci. 99:4188-4195.

Tang, Y., X. Yu, H. Chen, and Y. Diao. 2016. An immunoassay-based reverse-transcription loop-mediated isothermal amplification assay for the rapid detection of avian influenza H5N1 virus viremia. Biosens. Bioelectron. 86:255-261.

Tian, B., Z. Qiu, J. Ma, T. Z. G. de la Torre, C. Johansson, P. Svedlindh, and M. Stromberg. 2016. Attomolar Zika virus oligonucleotide detection based on loop-mediated isothermal amplification and AC susceptometry. Biosens. Bioelectron. 86:420-425.

Vithanage, N. R., M. Dissanayake, G. Bolge, E. A. Palombo, T R. Yeager, and N. Datta. 2016. Biodiversity of culturable psychrotrophic microbiota in raw milk attributable to refrigeration conditions, seasonality and their spoilage potential. Int. Dairy J. 57:80-90.

von Neubeck, M., C. Baur, M. Krewinkel, M. Stoeckel, B. Kranz, T. Stressler, L. Fischer, J. Hinrichs, S. Scherer, and M. Wenning. 2015. Biodiversity of refrigerated raw milk microbiota and their enzymatic spoilage potential. Int. J. Food Microbiol. 211:57-65.

Wan, C., Y. Yang, H. Xu, Z. P. Aguilar, C. Liu, W. Lai, Y. Xiong, F. Xu, and H. Wei. 2012. Development of a propidium monoazide treatment combined with loop-mediated isothermal amplification (PMA-LAMP) assay for rapid detection of viable Listeria monocytogenes. Int. J. Food Microbiol. 47:2460-2467.

Wang, Y., Y. Wang, A. Ma, D. Li, L. Luo, D. Liu, S. Hu, D. Jin, K. Liu, and C. Ye. 2015. The novel multiple inner primers-loop-mediated isothermal amplification (MIP-LAMP) for rapid detection and differentiation of Listeria monocytogenes. Molecules 20:21515-21531.

Weber, M., J. Geissert, M. Kruse, and A. Lipski. 2014. Comparative analysis of bacterial community composition in bulk tank raw milk by culture-dependent and culture-independent methods using the viability dye propidium monoazide. J. Dairy Sci. 97:6761-6776. 
Xin, L., L. Zhang, Z. Meng, W. Di, X. Han, H. Yi, and Y. Cui. 2017. Lipolytic psychrotrophic bacteria and lipase heat-resistant property in bovine raw milk of North China. J. Food Process. Preserv. 2017:e13289. https://doi.org/10.1111/jfpp.13289.

Xu, Y. G., L. M. Sun, Y. S. Wang, P. P. Chen, Z. M. Liu, Y. J. Li, and L. J. Tang. 2017. Simultaneous detection of Vibrio cholerae, Vibrio alginolyticus, Vibrio parahaemolyticus and Vibrio vulnificus in seafood using dual priming oligonucleotide (DPO) system-based multiplex PCR assay. Food Contr. 71:64-70.

Yang, H., X. Ma, X. Zhang, Y. Wang, and W. Zhang. 2011. Development and evaluation of a loop-mediated isothermal amplification assay for the rapid detection of Staphylococcus aureus in food. Eur. Food Res. Technol. 232:769-776.
Yang, W., X. Song, J. Wang, Z. Li, M. Ji, and Y. Li. 2014. Detection methods for milk pathogenic bacteria by loop-mediated isothermal amplification. Biosci. Trends 8:316-321.

Yang, Y. M., Q. Li, S. H. Wang, X. Q. Chen, and A. F. Du. 2016 Rapid and sensitive detection of Babesia bovis and Babesia bigemina by loop-mediated isothermal amplification combined with a lateral flow dipstick. Vet. Parasitol. 219:71-76.

Ye, L., Y. Li, J. Zhao, Z. Zhang, H. Meng, H. Yan, S. I. Miyoshi, and L. Shi. 2015. Development of a real-time loop-mediated isothermal amplification assay for the sensitive and rapid detection of Listeria monocytogenes. Lett. Appl. Microbiol. 61:85-90. 